\title{
HAEMATO-BIOCHEMICAL AND ANTIOXIDANT PROFILING OF INDIGENOUS CATTLE OF KASHMIR
}

\author{
Z. A. Pampori*, S. Ashraf, S. Iqbal, I. Nabi and R. Ahmad \\ Division of Veterinary Physiology, SKUAST- Kashmir, Shuhama, Alusteng, Srinagar - 190006-India
}

\begin{abstract}
Kashmir falls in the great north-western complex of the Himalayan ranges, at $34^{\circ}$ North and $76^{\circ}$ East with an average altitude of 1850 metres amsl. Indigenous cattle constitute $51 \%$ of total cattle population of the State. The evaluation of some important blood parameters in indigenous cattle for assessment of animal health status as well as course of variation in blood parameters in these animals was undertaken during summer to autumn, 2014. Twenty two indigenous cattle from different pockets of Kashmir valley were studied for haematobiochemical and anti-oxidative parameters. The values recorded for $\mathrm{Hb}$, PCV and MCV $\left(10.97 \pm 0.22 \mathrm{~g} \mathrm{dl}^{-1}, 36.45 \pm 0.55 \%\right.$, and $\left.67.71 \pm 1.76 \mathrm{fl}\right)$ respectively were on the higher side when compared to crossbreds or exotic cattle. TBARS and FRAP, measures of oxidant-antioxidant balance were $5.90 \pm 0.39 \mathrm{n} \mathrm{ML}^{-1}$ and $548.16 \pm 23.78{\mu \mathrm{ML}^{-1}}$ respectively, the values were on higher side when compared to exotic breeds. Similarly total protein, albumin and globulin levels reported were $8.27 \pm 0.22 \mathrm{~g} \mathrm{dl}^{-1}, 3.31 \pm 0.07 \mathrm{~g} \mathrm{dl}^{-1}$ and $4.95 \pm 0.20 \mathrm{gdl}^{-1}$ respectively that stands higher when compared to the reference values for cattle.Plasma biochemical analytes urea, creatinine, triglycerides, AST and ALT recorded in present study were comparable to the reference values for cattle. All these parameters provide complementary information about the homeostasis of indigenous cattle and indicate its good health status, higher disease resistance and good metabolic defence as compared to exotic or crossbred cattle in its temperate climate.
\end{abstract}

Keywords: Antioxidant status, blood constituents, indigenous cattle, plasma analytes,

\section{INTRODUCTION}

Cattle are one of the India's greatest biological resource (199.1 million, Livestock Census, 2007), which constitute nearly $13 \%$ of the world's total cattle population (Arjava Sharma, 2013). Many of the native breeds of cattle in India are giving way to the exotic and cross-bred animals. Exotic breeds like Holstein Friesian,

*Corresponding author email: drzap64@gmail.com

Received: 06.04.2015 
Jersey and their cross-breds are predominant in Northern parts of India including temperate regions of J \& K State (Mahima et al., 2013). Thirty recognised breeds in India constitute around 20 per cent of the country's total cattle population while around $80 \%$ of the cattle population is still non-descript. The existing indigenous cattle breeds have evolved over the centuries through natural selection for adoption to harsh climatic conditions, resistance to common diseases with ability to thrive under extreme nutritional stress. Under Intensive Cattle Development Project during fourth five year plan local cattle of the State were cross bred with Jersey and HF that resulted into $49 \%$ of cattle population presently in the State as crossbreeds. Realising the importance of indigenous germplasm, Indigenous Breeds Project (IBP) was undertaken in the country for preservation of indigenous breeds. About $70 \%$ of human population inhabits rural areas with domestic livestock like cow, sheep \& goat playing important role in their socio-economic status. The preservation of indigenous livestock has been now foreseen in Indian scenario because of being a low input and low output production system that can provide sustainability, food security, protein nutrition and even the empowerment to the rural families. Present study on blood physiology in indigenous cattle of Kashmir valley was undertaken because blood is of crucial importance for the maintenance of physiological equilibrium in the body. Certain blood biochemical constituents reflect the nutritional status/metabolic health of dairy herds with, or without, the manifestation of clinical abnormalities (Radostits et al., 2003). Further haematological and clinical chemical analysis of blood of animals is a potentially valuable diagnostic tool in animal health care for diagnosing various pathological and metabolic disorders that can adversely affect the productive and reproductive performance of animals, therefore, various studies (Dutt et al., 1988; Pampori et al., 2010 and Pampori et al., 2011) have documented hematobiochemical parameters in domestic species. The present study in Kashmiri indigenous cattle could provide the reference values of haemato-biochemical parameters that are important for the clinical interpretation of laboratory data and a valuable diagnostic tool in animal health care.

\section{MATERIALS AND METHODS}

The present study was conducted in 22 apparently healthy indigenous Kashmiri cows of 4-6 years age, from remote pockets of Kangan and Bandipora areas of the Kashmir valley. The study was conducted in summer and autumn monthsduring the year 2014. The indigenous character of animals under study was ascertained on basis of the inputs from owners and their morphology (Plate-1). Seven millilitre of blood was collected with a 20 gauge needle from jugular vein in heparinised vacutainers after taking all necessary aseptic and ethical measures. Blood samples were transported to the laboratory on ice. Haematological parameters were studied immediately within 24 hours whereas plasma was separated by centrifugation and stored at $-20{ }^{\circ} \mathrm{C}$ for study of chemistry. Haemoglobin $(\mathrm{Hb})$ and packed cell volume (PCV) were estimated by cyanmethemoglobin method and microhematocrit method 
respectively. Total erythrocyte count (TEC) and total leukocyte count (TLC), Mean corpuscular volume (MCV), mean corpuscular haemoglobin $(\mathrm{MCH})$ and mean corpuscular haemoglobin concentrations $(\mathrm{MCHC})$ were determined as described by Feldman et al. (2000).

Plasma was evaluated for a wide range of analytes _ viz total protein (TP), albumin (Alb), urea, creatinine, triglycerides, aspartate aminotransferase (AST), alanine aminotransferase (ALT) using kits from Coral Clinical Systems, India. Thiobarbituric acid reactive substance (TBARS), an index of oxidative stress, was evaluated by the method described by Asakawa and Matsushita (1980). The ferric reducing ability of plasma (FRAP), a measure of antioxidant power, was determined by a method described by Benzie and Strain (1996).

Data recorded were subjected to statistical analysis using Microsoft office Excel 2007 software and values are presented as mean \pm standard error.

\section{RESULTS AND DISCUSSION}

The mean values recorded for $\mathrm{Hb}, \mathrm{PCV}$, TEC, TLC, MCH, MCHC and MCV are presented in table 1. The values recorded in present study for $\mathrm{Hb}$ and PCV were on the higher side when compared to the values reported in crossbred cows (Mir et al., 2008, Kumar and Pachauri, 2000 and Khan et al., 2011) and in exotic cattle (Sattar and Mirza, 2009). However present recorded values for haematology in indigenous cattle were similar to the reported values in Haryana cattle (Mahima et al., 2013). Haemoglobin and packed cell volume were included in metabolic profile tests amongst other biochemical constituents (Payne et al., 1970), hence, present findings indicate a good metabolic status of indigenous Kashmiri cattle. Present values for erythrocyte indices MCV and MCH were also on higher side when compared to the values in Haryana (Mahima et al., 2013), in crossbred cattle (Kumar and Pachauri, 2000) and in Sahiwal (Ahmad, 1995). The importance of erythrocyte indices in interpretation of metabolic profile tests in cattle was discussed by Jazbec et al. (1993). Higher PCV in present study could be directly related to higher MCV which is an index of RBC volume and probably indigenous cattle had larger erythrocyte volume with high corpuscular haemoglobin. Further higher $\mathrm{MCH}$ reported in present study in indigenous cattle may be an adaptation to the high altitude topography of Kashmir with its TEC not much different from the reference values for cattle (Pampori, 2003).

The mean values for oxidative stress markers TBARS and FRAP and plasma biochemical analytes urea, creatinine, TP, Albumin, Globulin, A/G ratio, ALT, AST and TG recorded in local cattle are presented in table 2.

TBARS and FRAP a measure of lipid peroxidation and antioxidant status respectively have now been extensively studied to assess the oxidative stress which provides a good reference of animal homeostasis. Evaluation of oxidative stress has contributed increasingly to our knowledge of the fundamental mechanisms involved 
in metabolic challenges, especially important in domestic animals in which many physiological process like lactation, pregnancy impose physiological demands on animal homeostasis (Castillo et al., 2006 and Pampori \& Pandita, 2013). The antioxidant status recorded as FRAP in Kashmiri indigenous cattle was on higher side when compared to the values in buffaloes (Pampori \& Pandita, 2013). However TBARS recorded in present study in local cattle were on higher side when compared to the reported values in crossbred Holstein cattle (Chaiyabutr et al., 2011).The use of TBARS and FRAP values, measures of oxidant-antioxidant balance, could provide complementary information about the homeostasis of the animal than conventional metabolic parameters alone. Higher antioxidant capability reported in local Kashmiri cattle supports the view that local cattle are more resistant to extreme stress condition.

The plasma concentration of various biochemical analytes reported in indigenous cattle of Kashmir valley were comparable to the reference values for cattle (Mary, 2004 and Pampori, 2003). However total protein and globulin levels reported in present study were on higher side even higher than the values reported in Yak hybrids of Kashmir (Pampori et al., 2010). The higher concentration of globulin fraction may account for higher disease resistance in local cattle as compared to crossbred, further holds the view that local cattle are more disease resistant than exotic. The levels of creatinine and total proteins reported in indigenous cattle of Bangladesh by Mamun et al. (2013) were higher and lower respectively as compared to the values reported in present study that suggests a healthy status of indigenous cattle of Kashmir.

\section{CONCLUSION}

Present study documented the baseline values for various important blood parameters in indigenous cattle of Kashmir which were not available and can serve indices in diagnosis of various productive and reproductive ailments. From the present study it gets established that the antioxidant status on indigenous cattle was on higher side as compared to crossbreds and European breeds which confers higher resistance to these animals against stresses thus more sustainable.

\section{REFERENCES}

Ahmad, I. 1995. Antibody titer and hematology following vaccination and immunepotentiation of Sahiwal cows in last trimester of pregnancy. Ph. D.Diss. University of Agriculture, Faisalabad, Pakistan

Arjava Sharma. 2013. Project Directorate on Cattle. Indian Council of Agricultural Research. Grass Farm Road, Meerut Cantt. (U.P.), India. (htpp://www.pdcattle.org.in)

Asakawa, T. and Matsushita, S. 1980. Coloring conditions of thiobarbituric acid test for detecting lipid hydroperoxides. Lipids, 15: 137-140 
Benzie, I. F. F. and Strain, J. J. 1996. The Ferric Reducing Ability of Plasma (FRAP) as a measure of "antioxidant power" The FRAP Assay. Analytical Biochemistry, 239: 7076

Castillo, C., Herna'ndeza, J., Valverde, I., Pereira, V., Sotillo, J., Lo'pez Alonso, M. and Benedito, J. L. 2006. Plasma malonaldehyde (MDA) and total antioxidant status (TAS) during lactation in dairy cows. Research in Veterinary Science, 80: 133-139

Chaiyabutr, N., Chanchai, W., Boonsanit, D., Sitprija, S. and Chanpongsang, S. 2011.

Different responses of oxidative stress index in the plasma of crossbred Holstein cattle during cooling and supplemental recombinant bovine somatotropin. Journal of Animal and Veterinary Advances, 10: 1045-1053

Dutta, J. C., Baruah, R. N., Dutta, L. and Talukar, S. C. 1988. Blood biochemical studies in anoestrus and normal cyclic cattle. Indian Veterinary Journal, 65: 239-41

Feldman, B. F., Zinkl, J. G. and Jain, N. C. 2000. Schalm's Veterinary Haematology. Lippincott Williams and Wilkins. USA

Jazbec, I., Zadnik, T., Modic, T., Lobnik, R., Praprotnik, A., Klinkon, M. and Nemec, M. 1993. Haematological, biochemical and carpological profile in dairy cows of Radlje. Znanost in Praksa v Govedoreji (Slovenia), 17: 185-196

Khan, I. A., Khan, A., Hussain, A., Riaz, A. and Aziz, A. 2011. Hemato-biochemical alterationsin cross bred cattle affected with bovine theileriosis in semi-arid zone. Pakistan Veterinary Journal, 31: 137-140

Kumar, B. and Pachauri, S. P. 2000. Haematological profile of crossbred dairy cattle to monitor herd health status at medium elevation in Central Himalayas. Research in Veterinary Science, 69: 141-145

Mahima Singh, K. V., Verma, A. K., Kumar, V., Singh, S. K. and Roy, D. 2013. Hematological and serum biochemical profile of apparently healthy Haryana cattle heifers in Northern India. Pakistan Journal of Biological Science, 16: 1423-1425

Mamun, M. A., Hassan, M. M., Shaikat, A. H., Islam, S. K. M. A., Hoque, M. A., Uddin, M.

and Hossain, M. B. 2013.Biochemical analysis of blood of native cattle in the hilly area of Bangladesh. Bangladesh Journal of Veterinary Medicine, 11: 51-56

Mary Anna Thrall. 2004. Veterinary Hematology and Clinical Chemistry. Lippincott Williams and Wilkins, Philadelphia

Mir, M. R., Pampori, Z. A., Iqbal, S., Javeed, I. A., Pal, M. A. and Manzoor, A. K. 2008. Hemato-biochemical indices of crossbred cows during different stages of pregnancy. International Journal of Dairy Science, 3(3): 154-159

Pampori, Z. A. 2003.Field cum Laboratory Tests in Animal Health Care. Daya Publications, New Delhi, India

Pampori, Z. A., Iqbal, S., Hasin, D. and Iqbal, M. 2010. Haematology and serum chemistry of Zomo, Tulmo and Garmo (Yak hybrids). Indian Journal of Dairy Science, 63(1): 74-78

Pampori, Z. A., Iqbal, S., Khan, M. Z. and Kirmani, N. A. 2011. Blood constituents and morphology of Yarqandi double humped camel. Indian Veterinary Journal, 88(4): 1920 
Pampori, Z. A. and Pandita, S. 2013. Gender and age bias in immune competence and oxidative stress markers in Murrah buffaloes (Bubalusbubalis). Indian Journal of Animal Science, 83: 717-724

Payne, J. M., Dew, S. M., Manston, R. I. and Margaret, F. 1970. The use of a metabolic profile test in dairy herds. Veterinary Record, 87: 150-158

Radostits, O. M., Gay, C. C., Blood, D. C. and Hinchciliff, K. W. 2003.Veterinary Medicine. Elsvier Science Ltd. USA

Sattar, A. and Mirza, R. H. 2009. Haematological parameters in exotic cows during gestation and lactation under subtropical conditions. Pakistan Veterinary Journal, 29(3): 129132 
Table 1. Haematology of indigenous Kashmiri cattle

\begin{tabular}{ll}
\hline Parameters & Values $(($ Mean \pm SE $)$ \\
$\mathrm{Hb}\left(\mathrm{g} \mathrm{dl}^{-1}\right)$ & $10.97 \pm 0.22$ \\
$\mathrm{PCV}(\%)$ & $36.45 \pm 0.55$ \\
$\mathrm{TEC}\left(10^{6}\right)$ & $5.44 \pm 0.12$ \\
$\mathrm{MCV}(\mathrm{fL})$ & $67.71 \pm 1.76$ \\
$\mathrm{MCH}(\mathrm{pg})$ & $20.45 \pm 0.57$ \\
$\mathrm{MCHC}(\mathrm{g} \%)$ & $30.28 \pm 0.66$ \\
$\mathrm{TLC}\left(10^{3}\right)$ & $5.46 \pm 0.22$ \\
\hline
\end{tabular}

Table 2. Plasma chemistry and oxidant-antioxidant markers of indigenous Kashmiri cattle

\begin{tabular}{ll}
\hline Parameters & Values $(($ Mean \pm SE $)$ \\
Urea $\left(\mathrm{mg} \mathrm{dl}^{-1}\right)$ & $30.10 \pm 1.47$ \\
Creatinine $\left(\mathrm{mg} \mathrm{dl}^{-1}\right)$ & $1.70 \pm 0.02$ \\
Total Protein $\left(\mathrm{g} \mathrm{dl}^{-1}\right)$ & $8.27 \pm 0.22$ \\
Albumin $\left(\mathrm{g} \mathrm{dl}^{-1}\right)$ & $3.31 \pm 0.07$ \\
Globulin $\left(\mathrm{g} \mathrm{dl}^{-1}\right)$ & $4.95 \pm 0.20$ \\
A/G ratio & $0.69 \pm 0.03$ \\
TG $\left(\mathrm{mg} \mathrm{dl}^{-1}\right)$ & $59.71 \pm 3.26$ \\
AST $\left(\mathrm{U} \mathrm{ml}^{-1}\right)$ & $169.36 \pm 2.05$ \\
ALT $\left(\mathrm{U} \mathrm{ml}^{-1}\right)$ & $53.47 \pm 2.83$ \\
TBARS $\left(\mathrm{n} \mathrm{ML}^{-1}\right)$ & $5.90 \pm 0.39$ \\
FRAP $\left(\mu \mathrm{ML}^{-1}\right)$ & $548.16 \pm 23.78$ \\
\hline
\end{tabular}




\section{Plate-1}
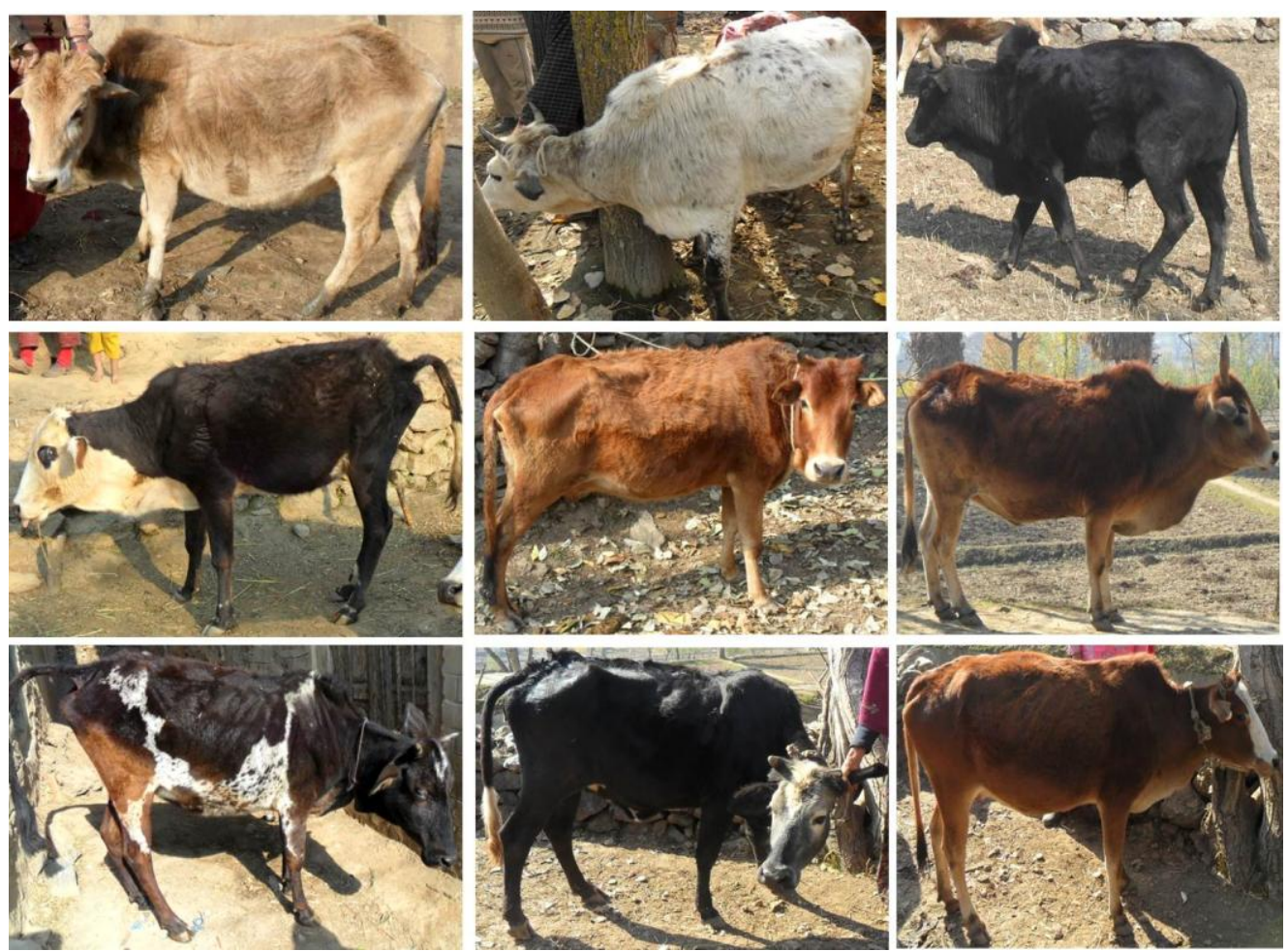